\title{
Universities seek to atone for Nazi past
}

[MUNICH] A university from the east has for the first time joined moves by some of Germany's older universities to address a murky aspect of their Nazi pasts. Rostock University on the remote Baltic coast is to search its archives for people whose academic qualifications were removed on racial or political grounds.

The university is planning to rehabilitate those who suffered in this way, even if in most cases this will have to be done posthumously. The first steps were discussed at the university last month.

The problem originated in 1933, when the Nazi government issued a law that stripped those who had decided to leave Germany because of persecution not only of German citizenship but also of academic qualifications, mostly doctorates.

Soon after, the law was extended to any German resident exhibiting 'antisocial behaviour' - a move targeted at Jewish, communist and dissident academics.

Each university was ordered by the min- istry of education to alter its rules to facilitate the derecognition of doctorates. Although the 31 universities then in Germany differed in the extent to which they applied the law, by 1945 an estimated 1,000 academics had lost their titles in this way.

After the war, partly in a bid to forestall intervention by the occupying Allied forces, universities in the new West Germany were quick to annul all decisions based on fascist ideology made in the Nazi era, including the derecognition of academic qualifications.

The 24 universities in the new West Germany each decided to restore academic qualifications to those from whom they had been stripped. But this was done only at the request of individuals whose cases would then be examined.

In contrast, the socialist regime in East Germany chose to build completely afresh, rather than reversing fascist laws and decisions. East German universities therefore did not feel it necessary to address the issue of derecognized qualifications.
Even in the West, however, movement was initially slow. In 1947, half of all West German professors were former members of the Nazi party. Indeed, a former chairman of a Nazi military court was even appointed rector at Marburg University. As a result universities were reluctant to look critically at their activities during the Third Reich.

Recently, however, this has changed. "The postwar generation started taking over the top positions in universities in the 1980s and 1990s," says Eckart Krause, a researcher in the faculty of history at Hamburg University. "This meant that universities gradually adopted more open-minded attitudes to their pasts."

In 1991 Hamburg became the first university in Germany to publish a report on its role in Nazi times. This included an official apology for the stripping of academic qualifications, and a statement declaring that the university now "derecognizes the derecognition" of qualifications.

Other universities, including Munich,

\section{Space 'time capsule' could send a message to the future}

[PARIS] A French artist is hoping to launch a satellite into orbit early next century that would return to Earth in 50,000 years, delivering a cargo of works of art and compact discs containing a contemporary 'library of Alexandria', as well as millions of messages from today's inhabitants of Earth. Its heat shield would create an artificial aurora borealis on re-entry, to alert the then inhabitants of the Earth to its arrival.

The craft, to be called Kéo as it comprises the only three sounds common to all languages, is the brainchild of the Parisbased artist Jean-Marc Philippe. Kéo, the 'archaeological bird', has been developed in collaboration with research and space organizations including the French Atomic Energy Commission, the Aerospatiale company, and Sup'Aero, the Toulouse-based grande école for aeronautics and space.

The same organizations, as well as the European Space Agency, are also backing another project of his to send the first sculpture to another planet, Mars. Both collaborations involve no direct funding, being developed through 'in kind' contributions of materials and time.

The French space agency CNES is seeking to arrange a free launch of Kéo on Ariane-5, according to Josette Runavot, deputy head of the agency's planetary exploration department, who points out that Ariane-5 is able to offer 'piggy-back' flights for small satellites alongside commercial payloads. The project is "marvellous", she says.

After establishing himself as a painter in

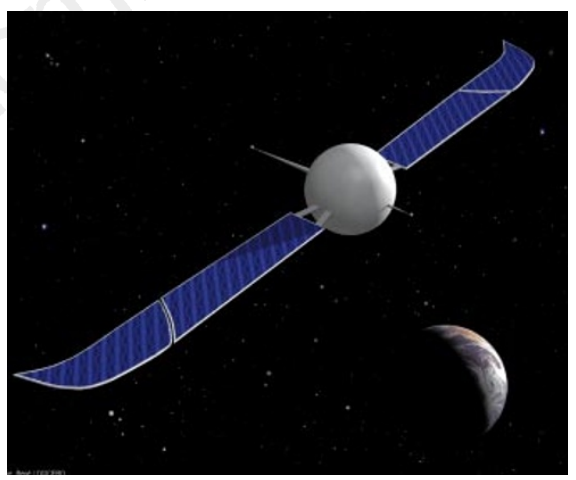

Round trip: Kéo, described as an 'archaeological bird', would return to Earth in 50,000 years time.

the 1970s, Philippe - who has a PhD in astrophysics - turned to developing new technologies to artistic ends. Through joint ventures with the US company Raychem and French research agencies, he has pioneered the development of 'shape memory alloys', compounds invented for use in US fighter aircraft that are able to 'memorize' precise shapes at various temperatures.

By adapting new technologies, artists can broaden creative possibilities, says Philippe. His work with alloys has yielded a copper-zinc-aluminium sculpture, 'Hermaphrodite', a bust of a male Greek torso at $20^{\circ} \mathrm{C}$ that changes to a woman's torso at $55^{\circ} \mathrm{C}$.

Kéo will have such sensitive alloys in its solar panels so they move up when the craft is in sunlight and down when it is in Earth's shadow, to give the appearance of a large gliding migratory bird. Inside the satellite samples of sea water, soil, air and a drop of human blood are held in a diamond, the surface of which is engraved with a highly conserved region of human DNA.

The capacity of the craft's titanium nitrate-plated glass discs is sufficient to store four pages of "uncensored" text from every inhabitant of Earth, says Philippe, who says the main aim of the project is to invite as much of humanity as possible to reflect on its history and destiny. He is preparing an international effort to collect text, and is in discussions with sociologists as to how the compilation could be exploited for research purposes.

For the second project, European space scientists have offered to trim the size of their instruments to make room for a threadlike sphere $10 \mathrm{~cm}$ in diameter containing a torus of shape-memory alloys that cause the sculpture to close during the cold martian night and open during the day to reveal a pyramidal diamond at its core, engraved with the DNA double helix. Philippe has submitted the sculpture to NASA's call for proposals for its Mars flights. But Marcello Coradini, coordinator of Solar System missions at the European Space Agency, says that if the bid is unsuccessful, his agency "will do its utmost" to fly the sculpture on its Mars Express probe.

Coradini argues that having a camera sending back images of a reactive artwork from Mars could be of "huge public interest".

Declan Butler 
Freiburg, Kiel and Frankfurt, have now also started going through their files to check for derecognition of doctorates and injustice in general in Nazi times.

Each university is proceeding in a different way, but all are checking every case individually. "We cannot and we do not grant a general rehabilitation," says Christian Winter, the vice-president of Frankfurt University.

"It is most important to discriminate between those who lost their titles on racial or political grounds and those who lost their titles on genuine criminal grounds."

Universities have found that it is not always easy to discriminate between the possibilities. Some cases are clear. For example, if the grounds for divestment of title were given simply as homosexuality or disloyalty to the Nazi regime, no longer crimes today, then rehabilitation would be automatic.

But if an academic was stripped of his or her title because of a financial offence, then the exact nature of the offence becomes important. Genuine criminal grounds were not unusual. Of 59 persons stripped of doctorates by Hamburg University, for example, eight were involved in genuine crime, including murder.

In the eastern part of Germany, some universities remain unaware of the issue - Rostock learned of its involvement only after being contacted by Nature. Other universities say they lack the resources to carry out time-consuming investigations.

For most of those affected, the efforts come far too late. Many have died, and it is difficult to track down those who are still alive. Aware of this, Munich University, in its 1996 statement reversing its own derecognition of 135 academic titles, described it as "first of all a gesture for the bereaved" with which the university "faces its responsibilities arising from its history". Matthiasstrobl

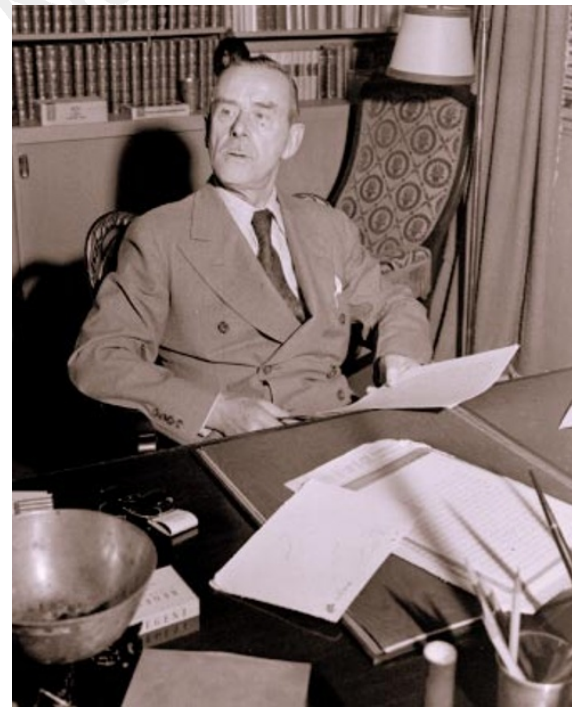

Honour regained: the author Thomas Mann was stripped of his honorary doctorate by the University of Bonn in 1936. It was returned to him on the university's initiative in $\mathbf{1 9 4 6 .}$

\section{Nobel laureates in bid to revamp science teaching}

[SAN FRANCISCO] A group that includes ten Nobel laureates will learn shortly whether it has been successful with its offer to restructure academic standards for California's science curriculum. The move follows a decision last month by a state commission to reopen a process under which the group's bid had earlier been rejected.

The Nobel prizewinners include such well-known names as David Baltimore, Glenn T. Seaborg, Henry Taube, Dudley Herschbach and Paul Berg, and the group is keen to counteract what its members regard as a 'dumbing down' trend in science education. It seeks to emphasize fundamental concepts and to ensure that schools produce competent students who will go on to science studies in colleges and universities.

The group says it would insist on wellwritten textbooks, scientifically trained teachers, better salaries for instructors, and a focus on basic scientific concepts and mechanisms. It suggests that students should begin physics in ninth grade (at 14 years of age), for example, and graduate with an understanding of Newton's laws of dynamics, elasticity, linear systems, electromagnetic mass, the laws of thermodynamics, and quantum behaviour, among other topics.

The group also proposes that students should start chemistry lessons in fifth grade and learn the periodic table and classification of elements, solubility, chemical equilibrium, atomic structure, chemical kinetics and thermochemistry, as well as other topics. In biology, it says, the emphasis should be on genetics and molecular biology.

The group argues that vague approaches to teaching science that fail to challenge students turn them off science and help create an environment where, for example, only 3 per cent of men and 1 per cent of women graduating from US universities have degrees in computer science.

Over the past decade, the number of students graduating in computer science in the United States has dropped by nearly a half, despite burgeoning job opportunities. Scientists must step forward to improve science education and to help lure more financial backing for better teaching laboratories, according to the group.

"(Scientists) are equipped and motivated to insist on teaching fundamentals and basics," says Seaborg, professor of chemistry at the University of California at Berkeley and a former chairman of the Atomic Energy Commission. Seaborg says that science deserves special attention in schools because so much of the job market now requires scientific or technological expertise.

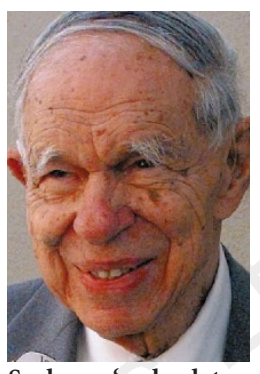

Seaborg: 'go back to basics in teaching'.
"Technology firms are hurting because they can't find people with elementary scientific knowledge," he says; even those in other fields need a basic understanding of science in order to perform adequately as citizens. Seaborg was the lead author of a 1983 report, A Nation at Risk, which detailed educational weaknesses and stimulated a wave of reforms.

The group, which calls itself Associated Scientists, was put together by Shoumen Datta, a molecular biologist who has been active in various education initiatives. Datta says he hopes that curriculum reform in California will stimulate a transformation of teaching methods throughout the country, helping to instil a general standard of excellence in US schools. "We are against the 'process, process' mentality in schools," he says, instead of a focus on accurate content.

Associated Scientists resubmitted its offer to shape academic standards, which it has said it is prepared to do at no cost, shortly before Christmas after a protest had forced the state commission for academic content and standards to rescind the offer of a contract made to another group.

The Institute for Science Education at California State University, San Bernardino, made up primarily of professional educators, had originally won the assignment with a bid costing $\$ 178,000$. One member of the commission's assessment team had explained its decision to award the contract to this group by saying the Nobel laureates "wouldn't know a classroom if you put it in front of them".

Marci McFadden, spokeswoman for the commission, subsequently argued that Associated Scientists had not included sufficient details about the education experience of its members, or the mechanisms by which they planned to accomplish their work. But when the State General Counsel informed the commission it had acted improperly in offering the contract to the San Bernardino institute, the bid process was reopened.

Final proposals were received in the week before Christmas, and the award to the winning contractor is due to be announced by 15 January. It is widely expected that the two teams will collaborate on the project, combining the San Bernardino group's expertise in education techniques with the Nobel laureates' knowledge of science.

SallyLehrman 